\title{
Necropolitics and Contemporary Hungarian Literature and Cinema
}

\author{
Ryan Michael Kehoe \\ Rice University
}

Follow this and additional works at: https://docs.lib.purdue.edu/clcweb

ర

Part of the Comparative Literature Commons, and the Critical and Cultural Studies Commons

Dedicated to the dissemination of scholarly and professional information, Purdue University Press selects, develops, and distributes quality resources in several key subject areas for which its parent university is famous, including business, technology, health, veterinary medicine, and other selected disciplines in the humanities and sciences.

CLCWeb: Comparative Literature and Culture, the peer-reviewed, full-text, and open-access learned journal in the humanities and social sciences, publishes new scholarship following tenets of the discipline of comparative literature and the field of cultural studies designated as "comparative cultural studies." Publications in the journal are indexed in the Annual Bibliography of English Language and Literature (Chadwyck-Healey), the Arts and Humanities Citation Index (Thomson Reuters ISI), the Humanities Index (Wilson), Humanities International Complete (EBSCO), the International Bibliography of the Modern Language Association of America, and Scopus (Elsevier). The journal is affiliated with the Purdue University Press monograph series of Books in Comparative Cultural Studies. Contact: <clcweb@purdue.edu>

\section{Recommended Citation}

Kehoe, Ryan Michael. "Necropolitics and Contemporary Hungarian Literature and Cinema." CLCWeb: Comparative Literature and Culture 11.4 (2009): <https://doi.org/10.7771/1481-4374.1562>

This text has been double-blind peer reviewed by $2+1$ experts in the field.

The above text, published by Purdue University Press (CPurdue University, has been downloaded 2232 times as of $11 /$ $07 / 19$.

This document has been made available through Purdue e-Pubs, a service of the Purdue University Libraries. Please contact epubs@purdue.edu for additional information.

This is an Open Access journal. This means that it uses a funding model that does not charge readers or their institutions for access. Readers may freely read, download, copy, distribute, print, search, or link to the full texts of articles. This journal is covered under the CC BY-NC-ND license. 


\section{PURDUE}

$\bar{U}$ N I V E R S I T Y UNIVERSITY PRESS <http://www.thepress.purdue.edu>

\section{CLCWeb: Comparative Literature and Culture}

ISSN 1481-4374 <http://docs.lib.purdue.edu/clcweb> Purdue University Press (C)Purdue University

CLCWeb: Comparative Literature and Culture, the peer-reviewed, full-text, and open-access learned journal in the humanities and social sciences, publishes new scholarship following tenets of the discipline of comparative literature and the field of cultural studies designated as "comparative cultural studies." In addition to the publication of articles, the journal publishes review articles of scholarly books and publishes research material in its Library Series. Publications in the journal are indexed in the Annual Bibliography of English Language and Literature (Chadwyck-Healey), the Arts and Humanities Citation Index (Thomson Reuters ISI), the Humanities Index (Wilson), Humanities International Complete (EBSCO), the International Bibliography of the Modern Language Association of America, and Scopus (Elsevier). The journal is affiliated with the Purdue University Press monograph series of Books in Comparative Cultural Studies. Contact: <clcweb@purdue.edu>

\begin{tabular}{c} 
Volume 11 Issue 4 (December 2009) Article 8 \\
Ryan Michael Kehoe, \\
"Necropolitics and Contemporary Hungarian Literature and Cinema" \\
<http://docs.lib.purdue.edu/clcweb/vol11/iss4/8> \\
\hline Contents of CLCWeb: Comparative Literature and Culture 11.4 (2009) \\
<http://docs.lib.purdue.edu/clcweb/vol11/iss4/>
\end{tabular}

Abstract: In his article "Necropolitics and Contemporary Hungarian Literature and Cinema" Ryan Michael discusses aspects of the concept of necropower (Mbembe) applied to contemporary Hungarian literature and cinema. Kehoe argues that his analysis provides models of postcolonial "aesthetic acts" that disrupt, destabilize, and ultimately subvert the global regimes to which Achille Mbembe refers. Accordingly, Hungary's status as a postcolony is discussed within the context of Steven Tötösy de Zepetnek's and David Chioni Moore's contention that the parameters of postcolonial cultural analysis need to be expanded to account for Central and East Europe's transition out of the Soviet sphere of influence. Further, Kehoe incorporates models of "transitology" from the discipline of comparative politics to the study of culture and literature of the region. Through an analysis of two contemporary Hungarian texts - László Krasznahorkai's novel War and War and Nimród Antal's film Kontroll - Kehoe analyses narrative strategies at work in not only the interrogation of necropower but also the construction of a politics of resistance. 


\section{Ryan Michael KEHOE}

\section{Necropolitics and Contemporary Hungarian Literature and Cinema}

In his 2003 article "Necropolitics" Achille Mbembe defines necropower as the global deployment of various technologies of occupation, domination, and exploitation that results in the creation of "deathworlds," or new kinds of social formations in which "vast populations are subjected to conditions of life conferring upon them the status of living dead" (40). Mbembe's argument is predicated on the assumption "that the ultimate expression of sovereignty resides, to a large degree, in the power and the capacity to dictate who may live and who must die" (11). Ranjana Khanna, summarizing Mbembe's understanding of sovereignty, observes: "Drawing on Agamben, and registering his departure from Foucault, Mbembe asks us to think of politics as a form of war, rather than as biopower" (<http://postcolonial.org/index.php/pct/article/view/385/815>). Thus, to think of politics as a form of war means to think of politics as necropolitics, the expression of which is necropower.

In my study, I postulate that the interrogation of necropower, a political act suffused with revolutionary intent, occurs at a textual level in localized cultural spaces and to that end argue that contemporary Hungarian literature and cinema provide models of postcolonial aesthetic acts that disrupt, destabilize, and subvert the global regimes to which Mbembe refers. Through an analysis of two texts: László Krasznahorkai's novel War and War and Antal Nimród's film Kontroll, I highlight various narrative strategies that participate in the interrogation of necropower and the construction of a radical politics of resistance. Accordingly, Hungary's status as "postcolony" is discussed within the context of Mbembe's interpretive framework and David Chioni Moore's (2001) and Steven Tötösy de Zepetnek's (1995-2002) assertion that the parameters of postcolonial cultural analysis need to be expanded to account for East Europe's transition out of the Soviet sphere of influence (on the development of the notion including the post-1989 impact of U.S. culture and economy on the region, see Lisiak). Further, I explore the efficacy of adopting so-called "transitological" approaches to the study of comparative politics to literary analysis in the interest of gesturing toward a theoretical explication of the role played by cultural production in the processes of democratization experienced by the nations formerly within the Soviet empire. Different conceptual models that many scholars of Central and East Europe have designed to account for the uniquely inflected movement out of authoritarian communism, among them the "trauma of transition" or the "melancholy of re-birth," allow for a nuanced study of the role literature plays during moments of extreme political upheaval or crisis. Transitology contributes to, as well as enhances, these approaches and opens up new spaces for critical intervention in the study of the Central and East European literary system.

For Mbembe, the technologies of necropower are expressed in their most radical and aggressive formations under the conditions of what he refers to as late-modern colonial occupation. According to Mbembe, whereas in the early-modern era, colonial occupation "was a matter of seizing, delimiting, and asserting control over a physical geographical area - of writing on the ground a new set of social and spatial relations," in the late-modern era "colonial occupation is a concatenation of multiple powers: disciplinary, biopolitical, and necropolitical" $(25,29)$. Mbembe's postulates include how under late-modern colonial occupation the politics of verticality have replaced older spatialized models and contribute to a redefinition of the relationship between sovereignty and space. Thus, according to the calculus of a politics of verticality, sovereignty is expressed through the surveillance and monitoring of multiple geographies that inhabit the same space which results in what he calls "splintering occupation," the policing and control of not just the ground, but airspace as well as subterranean tunnels, mineral reserves, munitions stores, bomb shelters, and so on (28). Mbembe devotes significant space in his article to the examination of the ways in which postcolonial states are particularly vulnerable to sophisticated technologies of surveillance and manipulation under the contemporary global regime of necropolitics. This contention is an elaboration of an argument he makes in an earlier work in which he states that "the postcolony is a particularly revealing (and rather dramatic) stage on which are played out the wider problems of subjection and its corollary, discipline" ("Provisional Notes" 3 ).

The vexed and contentious notion of just what constitutes the postcolonial, especially as it relates to the expansion of postcolonial theory's frontiers to include previously neglected geo-political spaces, has been the topic of debates within the fields of political science, literary and culture theory, as well 
as anthropology, and sociology. Tötösy de Zepetnek suggests that "Based on the assumption that the former USSR may be understood as centre by its political, military, economic, and ideological parameters in its relationships with its satellite countries, Central and East European literatures are understood as periphery in relation to the Soviet centre and consequently, as post-colonial situations" (40001 ) and that the region's condition of postcoloniality is problematized by the region's emergence, or transition, into a new "colonial situation dictated by economic and market forces controlled by the West European centre" (402) and Chioni Moore argues similarly for the necessity for "simultaneous critiques of both too narrow postcolonial and too parochial post-Soviet" (112) and that

the term "postcolonial" and everything that goes with it - language, economy, politics, resistance, liberation and its hangover - might reasonably be applied to the formerly Russo- and Soviet-controlled regions post-1989 and 1991, just as it has been applied to South Asia post-1947 or Africa post-1958. East is South ... When Russia moves its colonial enterprise to the West, the situation sharply changes, and I speak here principally of the post-World War II Soviet expansion to the independent Baltics and into nations such as Poland, Hungary, Czechoslovakia, Romania, and Bulgaria. By most classic measures - lack of sovereign power, restrictions on travel, military occupation, lack of convertible specie, a domestic economy ruled by the dominating state, and forced education in the colonizer's tongue - Central Europe's nations were indeed under Russo-Soviet control from roughly 1948 to 1989 or 1991. (115-21).

In many ways, then, Soviet imperial policies mimicked those of other historical empires and served as a basis or justification for repressive, sometimes violent interventions into the domestic affairs of the East Central European satellite countries.

A brief historical overview of the evolutionary trajectory of the Hungarian state supplements Tötösy de Zepetnek's and Chioni Moore's theoretical propositions, thus to build a conceptual bridge between the consideration of Hungary's postcoloniality and the introduction of theoretical approaches to contemporary Central and East European textual politics and the interrogation of necropower. Tötösy de Zepetnek's notion includes the proposition that there is a kind of dual-peripheralization he designates "in-between peripherality" of the region's cultures whereby certain cultural and political anxieties were felt as a function of the pressures exerted by two distinct and powerful colonial centers, i.e., the West and the Soviet Union (see, e.g., "Configurations of Postcoloniality"). Applying Mbembe's notion of necropolitics, because of its tenuous position of having been subjected to the competing ideologies at play during the global regime of bi-polarity which defined the Cold War, Hungary was simultaneously under the conditions of early-modern and late-modern colonial occupation. Occupied militarily by the Soviet Union 1947-1989 and experiencing the importation - both from the Soviet Union and by Hungarian communists - of Marxist-Leninist models of social, economic, and political organization, Hungary was a colonial holding of the Soviet empire. After the failure of the 1956 Revolution, the newly appointed Secretary-General of the Hungarian Socialist Workers' Party János Kádár established a tacit social contract between the governing authorities and the population. After an initial period of readjustment, the leaders in Hungary began to experiment with the liberalization of certain aspects of society, most notably allowing through the New Economic Mechanism (1966) limited free-enterprise and the increased importation of luxury items from the West. Travel restrictions were also eased, thereby allowing for greater mobility and increased exposure to Western juridico-political norms creating a proliferation of different kinds of contact zones and nuanced forms of interaction. The New Economic Mechanism, reinforced by an increasingly assertive attitude of self-determination in foreign and domestic policy, as well as the insistence that it not be regionally identified according to the standard East-West model but as part of Central Europe, allowed Hungary to mediate the tensions between the two major competing ideological systems, communist and capitalist. After the Fall of the Berlin Wall, by the mid-1990s, a growing propertied class whose members include former communist party officials - who benefitted from privatization after 1989 -began clamoring for greater access to the unrestrained possibilities for the accumulation of wealth. The political establishment began lobbying for Hungary's accession to NATO and the European Union, which were ultimately extended in 1999 and 2004, respectively, thus solidifying the country's movement toward Western models of social and political organization. Moreover, the United States and its allies, by incentivizing military participation in the various misadventures in the Middle East with the prospect of eventual full incorporation into the 
hyper-neo-liberal nexus of institutional arrangements and power formations have been able to assert a kind of late-modern colonial occupation of Hungary (on this, see also Lisiak). This new kind of colonization is directed and executed by actors who are interested not just in resource extraction or territorial expansion, but with the organization of entire populations into manageable groups over which they can exercise the most extreme and destructive forms of necropower.

In its contemporary post-communist geo-spatial relationships to the rest of Europe, Hungary has continued to struggle with the problematics of regional identification. Immediately after the collapse of the communist system, institutions such as universities and other government-aligned groups attempted to maintain and market the country and its culture as a Central European space which they felt allowed it to draw a distinction between itself and what is perceived to be the lawless, violent, and impoverished East of Central Europe while at the same time promoting a kind of Hungarian exceptionalism which rejected incorporation into the West (see, e.g., Braun and Barany). This maneuver was part of an overall project of cultural essentialism which exploited a repressed nostalgia for its former status as a powerful kingdom and important player in world affairs. Moreover, it encouraged, to a certain degree, irredentist fantasies inspired by continued anger over what is generally perceived to have been the un-necessarily punitive Treaty of Trianon (1919). The problematics of regional identification extend beyond the concerns of tourism ministries of the former Warsaw Pact countries; they are embedded deeply within various theoretical approaches to the study of political science and, more specifically, what has come to be known in post-Soviet or post-communist studies as the Transition Age. Beverly Crawford and Arend Lijphart address this issue in their article "Explaining Political and Economic Change in Post-Communist Eastern Europe: Old Legacies, New Institutions, Hegemonic Norms, and International Pressures." For Crawford and Lijphart, debates in the field of comparative politics between those who advocate what they refer to as the "legacies of the past" and the "imperatives of liberalization," approaches to the study of democratic transition should not be read necessarily as unduly antagonistic. In fact, taken together, these two critical frameworks have the potential to more completely and effectively explain the nature of individual nations' experiences with the difficulties of transitioning out of one politico-disciplinary regime into another.

More than just a matter of debate among political scientists, economists, or policy practitioners, the relationships between regional identification, uniquely defined colonial (and postcolonial) situations, and the development of textual responses to different conditions of subjection or manipulation provide a multitude of possibilities for cultural analysis. Metaphorical readings of the Central and East European transition out of authoritarian communism and into the contemporary global regime of the necropolitical establish connective lines of inquiry to the work of some scholars who read the instant of emergence as one fraught with collective feelings of anxiety and uncertainty for the former Eastern Bloc nations. In an analysis of contemporary Central European cinema, Catherine Portuges defines the moment of transition out of the Soviet sphere of influence as a traumatic event, a "passage from euphoria to disillusionment and its accompanying rhetorical shift from 'East' to 'Central' Europe" (134). This "trauma of transition" or what György Konrád refers to as "the melancholy of rebirth" resonates with the development within post-Soviet studies of transitology: an area of comparative political analysis concerned with the movement of nations out of one political regime into another. As a supplement to the theoretical and applied frameworks suggested by Konrád, Chioni Moore, Portuges, and Tötösy de Zepetnek, transitology not only establishes a foundation from which it is possible to consider Hungary's status as postcolony, but also contributes to and reinforces the allegorical interpretations of the narrative strategies employed by writers in the former socialist camp.

Developed primarily as a response to what were perceived to be by many scholars within the political science establishment as the inadequacies or shortcomings of modernization theory, transitology is a sub-field of comparative politics that theorizes the evolutionary trajectories of nation-states out of authoritarianism. Originally constructed to explain the processes of democratization experienced by nations in Latin America during the 1970s, transitology appears to be a ready-made interpretive framework for analyzing Central and East Europe's transition from communism to liberal democracy. As Guillermo O'Donnell and Philippe Schmitter argue in their Transitions from Authoritarian Rule: Tentative Conclusions about Uncertain Democracies, proponents of transitology subscribe to three fundamental propositions about the process of democratic transition. First, they argue that in order for democracy to take root, no set of preconditions needs to be in place other than a preexisting agreement 
over the territorial boundaries of the nation-state. Second, the most successful transitions are conducted via diplomatic negotiations between representatives of both the former authoritarian regime and the democratic opposition. And Jordan Gans-More, in his article "Searching for Transitologists: Contemporary Theories of Post-Communist Transitions and the Myth of a Dominant Paradigm," summarizes O'Donnell's and Schmitter's third proposition in which "different patterns of elite interaction or different modes of transition - impact the prospects for democratization and influence the institutional features and quality of the democracy that emerges" (326). Thus, transitology offers certain disciplinary assumptions; for example, it stresses the productive capacity of trans-regional comparison in order to interpret the wide-ranging, and occasionally disparate, forms of democratization. To accomplish this, transitology assumes little, if any differences, exist between kinds of authoritarian regimes: military dictatorships, Marxist-Leninist or totalitarian fascist regimes, or traditional one-party states (e.g. Mexico's experience or the dominance of the Liberal Democratic Party in Japan). Moreover, many transitologists operate under the guiding principle that liberal democracy is the logical outcome of the transition process, thereby eliding the possibility of or failing to account for the movement out of one form of authoritarianism into another. Many critics of the transitological approach, therefore, point out that it offers no explanation for the experiences of contemporary post-Soviet states like Belarus or Turkmenistan, or, according to some left-leaning political scientists, it assumes that the global regime of neoliberalism (or necropolitics) is an ideal developmental telos (see, e.g., Bunce).

While not quite willing to abandon transitology because of the many criticisms of the approach, some scholars have argued for a more nuanced form of analysis that adopts certain aspects of the theory in order to more fully explain the transition process. In his article "From Eastern Empire to Western Hegemony: East Central Europe under Two International Regimes," Andrew Janos discusses the utility of the four dominant interpretive paradigms within comparative politics that are employed to explain the collapse of the Soviet empire. These constructs range from "evolutionary scheme[s]" that present the implosion of Really Existing Socialism "as a triumph of human rationality," to those that argue "that the demise of communism resulted from tensions between the ever-increasing complexity of the economic base and the continued backwardness of the political superstructure" (221). Ultimately, Janos argues for the employment of a new paradigm, "one that describes the changes experienced by the small states of East Central Europe as part of a process of transition, though not from authoritarianism to democracy but from one international regime to another" (222). Janos's argument is more than an extended polemic against traditional transitological approaches to political analysis which have been criticized by scholars like Valerie Bunce for being overly reliant on teleological formulae and too narrow to account for the unique cultural and social contexts of Central and East Europe; rather, Janos emphasizes and elaborates upon transitology's insistence on the metaphor of movement, transit, in order to highlight the fluidity and uneven or unpredictable nature of the individual and national developmental or evolutionary project. In this sense, Janos's critical manipulation of transitology, and most importantly, its concern with the necessity for comparative work across regions and cultures, lays the theoretical foundation for an approach to cultural and textual analysis that has the potential to offer new insights into how literary production influences, and is influenced by, national transitions out of authoritarian pasts. Critiques of transitology notwithstanding, as a spatio-temporal metaphorical structure it allows for the analysis of the narrative strategies employed by Krasznahorkai and Antal in order to determine their ability to interrogate effectively necropower at a textual level.

Hungary's status as a post-Soviet postcolony, as well as its contemporary struggles with regional identification, and its recent interpellation into the nexus of overlapping and sometimes conflicting networks of power formations and disciplinary structures known as necropolitics, encourages transitological approaches to comparative cultural analysis. Beatrice Töttössy elaborates upon Tötösy de Zepetnek's initial proposition in order to analyze the "epistemological bases of contemporary Hungarian literature in its postmodern manifestations of the literary text" (881). She observes that Hungary "is changing from a society founded on mass Socialist Realist inspired paradigms of communication characterized by 'compact' communication, planned and orchestrated ... to a society based on a different type of mass communication of infinite individual texts" (883). Töttössy argues that in its primary stage of development, "Hungarian postmodern literature tries to produce a new writing, a textuality whose form is content" (889). Furthermore, she asserts that one of the main characteristics that defines Hungarian postmodern literature is its culturally and politically motivated desire to escape 
from or emerge out of older Socialist Realist structural paradigms which constrained the development of individual (as well as social) consciousness. Töttössy alludes to the metaphor of transit to describe the development of post-Soviet Hungarian textual and communicational structures of meaning: "By the 1990s, the Hungarian literature of "transit ... between two points which remain both present and available ... between the memory of Modernism and the post-modern creativity that elaborates it, shows itself as the level on which a déjà vu-deja lu system is transplanted - a system belonging to the recent and immediate past - to keep account of the laws of ecology of the communicative mind and, over all, of its essential nucleus, the aesthetic-linguistic fantasy" (883-84). Here, the parallels to transitological modes of sociological analysis are clear: the cultural politics inherent in the movement from one generic construct or form of consciousness to another, i.e., modernism to the post-modern. And György Kálmán, in his article "After Dictatorships: Transition, Modernity, Post-Modernity and Power," makes the assertion that "Modernity has a somewhat different connotation in the eastern part of Europe" and that "globalization raises quite special problems in this part of the world" (63). For Kálmán, what he defines as the "modern" is a "special temper or disposition," or "a way of seeing or perhaps rather making the world" (64). In other words, what lingers beneath the surface is an interpretation of the ways in which Hungary's emergence out of authoritarian socialism into the contemporary global regime of necropolitics solicits textual responses of subversion and resistance, hence my interest in Hungary's literary and cinematic production representing the said paradigm.

For many Central and East European scholars of literature and culture, the "legacies of the past" inform and sometimes complicate the trajectory of cultural development in its localized contexts. During the era of Soviet imperial control of the region, Zhdanovite cultural policy reigned supreme. Inspired by the lofty goal of creating the New Soviet Man, political authorities in Moscow, through their proxies in the satellite states, demanded strict adherence to the guidelines of socialist realism. In effect, this meant the creation of a new official canon, as well as the beginning of a new literary tradition. Constituting a violent rupture or aporia in the development of the national literatures of the region, Zhdanovism limited strictly the kinds of works that could enter into an economy of mass cultural consumption. Ultimately, the ideal Socialist Realist text "was supposed to have a decodable meaning, a clear referential character, an indisputable representational relation to what was supposed to be reality" (Kálmán 66). While the Zhdanovite intervention constituted a break in the development of modernism behind the Iron Curtain, it also had the effect of valorizing the classical literatures of the nations of the Warsaw Pact. Moreover, it allowed for the development of various critical and theoretical approaches which many scholars employed in their critiques of works within the officially sanctioned canon. As Kálmán observes, during the tumultuous 1960s in Hungary, partially as a reaction to the Soviet military response to the 1956 Revolution, scholars within the literary critical establishment began re-interpreting classical and socialist realist texts by engaging in a so-called "counter-reading" or a "reading between the lines, searching for Modernism in the seemingly Classical, finding the disharmony behind the smooth surface" (67). In this sense, politically inflected Modernism became a means of reading or interpreting rather than a mode of literary production. This subversive practice was a way to undermine the power of the cultural (i.e., political) authorities as the actual artifacts under consideration remained the same canonical works on the approved reading lists.

While the interpretation of classical works remains robust in Hungary, especially the focus on nineteenth-century texts, a politically motivated shift in emphasis towards the complex narrative structures of postmodern literature is now evident. Two contemporary postmodern Hungarian texts that are products of the primary stage of development to which Töttössy refers are Krasznahorkai's novel War and War and Antal's film Kontroll. The ludic nature of these postmodern narratives allows for the subversion and displacement of the old Soviet colonial imperatives and opens up new modes of communication and new kinds of aesthetic-linguistic political acts that also participate in the resistance against contemporary forms of necropower. In Kontroll, Antal exposes the viewer to a cinematic representation of the kind of social formation that Mbembe refers to as a death-world. The "living dead" that occupy and negotiate their way through the cavernous space of the Budapest underground are members of a team of ticket inspectors, a kind of police force which has the unfortunate mandate to ensure that all travelers on the system have tickets or passes. This team of inspectors, led by Bulcsú, as a dark and brooding character with a mysterious past, boards the trains secretly and only then do they reveal themselves as agents of the state by donning the dreaded armband: a red and white sig- 
nifier of authority and surveillance that immediately recalls the nazi occupation of Hungary and the fascist Arrow Cross dictatorship. Bulcsú inhabits the subterranean space of the subway system by choosing to live twenty-four hours a day in the tunnels and passageways, fearful of returning to the surface and the life he has abandoned - a life that was, according to various cryptic clues provided to the viewer in the narrative, full of personal and professional successes. Now in self-imposed exile below the surface and charged with hunting down a shadowy figure who is pushing unsuspecting passengers in front of speeding subway trains, Bulcsú finds himself in the precarious position of enforcing the dictates of a necropower he resists. His eventual emergence from the subterranean depths of the Budapest subway system after an ambiguous episode in which he confronts the figure, his double or Doppelgänger, can be read as a kind of quasi-theological narrative of resurrection which reinforces his earlier act of martyrdom.

In his review of the film, "Subterranean Dreaming: Hungarian Fantasies of Integration and Redemption," Steve Jobbitt observes that "it should be noted from the start that Antal never intended Kontroll to be about Hungary per se, nor did he intend it to be a commentary on contemporary Hungarian fantasies of integration and redemption" (<http://www.kinokultura.com/specials/7/kontroll.shtml>). Ultimately, however, Jobbitt concludes that "Antal has managed to channel existing discourses, emotions, and perceptions into a visual narrative that gives us, the viewers, access into the conflicted psyches of a society perched anxiously and, according to Žižek, hopelessly - on the cusp of social, political, economic, and cultural integration" (<http://www.kinokultura.com/specials/7/kontroll.shtml>). Much of Jobbitt's argument is concerned with the variously configured gendered aspects of Antal's narrative, specifically in his discussion of Szofi's roles as caretaker and savior for both Bulcsú and her father Béla. The most relevant parts of his discussion in terms of the argument presented here, however, deal with the film's representation of the problematics associated with Hungary's emergence from Soviet imperial control into the domain of what Mbembe refers to as the necropolitical. Whether as a function of Hungary's subjection to the harsh austerity measures and other demands imposed by the so-called "Copenhagen Criteria," or as the result of what some Hungarians felt was an all too eager embrace of Western models of economic and social policy, Jobbitt is right in his diagnosis that the nation's contemporary political situation is one of collective anxiety or even disappointment with its post-transition reality.

Placing the issue of gender aside, the question becomes to what extent is Bulcsú's final "defeat" of his Doppelgänger and his ultimate emergence from the Budapest underground somehow representative or suggestive of what Jobbitt contends is the absence of a kind of narrative resolution to the film, an absence which reveals something about contemporary Hungary's socio-political condition. Beyond addressing "an undeniably masculine fantasy of [European] integration and redemption" (<http://www.kinokultura.com/specials/7/kontroll.shtml>). Bulcsú's abandonment of the cavernous spaces of the Budapest subway system signifies something much more ominous: Hungary's transition out of Soviet orbit and subsequent interpellation into an inter- or trans-national regime of repressive political and economic manipulation and control. Ultimately, Jobbitt's critique of Antal's film does not go far enough. While Kontroll certainly addresses collective national anxieties associated with Hungary's accession to the European Union and the processes associated with European integration, Jobbitt's historical analyses stop short of addressing the nation's experience as a postcolony and its contemporary position within a highly-regulated, totalitarian capitalist world system. Thus, Bulcsú's final ascent up the escalator should be read as an example of Antal's politico-aesthetic practice of subversion of and resistance against the necropolitical in that it is an allegorical representation of Hungary's emergence from what Mbembe refers to as a death-world: a new kind of social formation which calls into question certain models of subjectivity and global citizenship. Bulcsú's story, to a certain extent, resonates with and serves as a counter-point to that of György Korin, the 'hero' of Krasznahorkai's Kafkaesque novel War and War first published in Hungarian in 1999 and later translated by George Szirtes in 2006. The novel is divided into eight chapters each broken down into numerous sections ranging in length from just a few lines to several pages. These sections are composed of single, meandering sentences that establish an ever-widening kaleidoscopic field of vision in which every action and thought is meticulously recorded, imitating or reproducing on the level of narrative the archival work of the protagonist. This mode of presentation is what Matthew Spellberg has called "the sublime ordering

mechanism of Krasznahorkai's absurd and sometimes terrifying world"


(<http://www.hcs.harvard.edu/ hbr/issues/8.1summer06/articles/warwar.shtml>). He goes on to observe: "his rich descriptions are exquisite explorations of consciousness, perception and memory. But without the momentary totality that they attain at the end of each chapter and again upon the book's completion, they might simply be discursive and wordy. They conflate time and space, but then overrule the conventions of both in favor of something far more beautiful. More beautiful than any moment, than $\quad$ perhaps
(<http://www.hcs.harvard.edu/ hbr/issues/8.1summer06/articles/warwar.shtml $>$ ).

life"

The novel begins in media res with Korin surrounded on a railroad platform by a ruthless gang of pre-adolescent criminals who have determined that he is too pathetic to molest and who decide instead, for reasons that even they do not understand, to sit and listen as he narrates the events of his life that have brought him to this place. Thereafter, the novel begins the work of engaging with questions of history and memory, both personal and national, as we learn that Korin, a low-level civil servant, has discovered in the archive in which he works a manuscript while rifling through and cataloguing the documents of the Wlassich family (80). The archive, here figured as the repository of national memories, can be within the context of Hungarian history interpreted as another kind of death-world. In the archive are the records of all of the arrests, tortures, forced confessions, and executions that have occurred in Hungary's multiple experiences with imperial and authoritarian politics, grand narratives, and other kinds of ideological systems under which it has suffered. Korin, responding to the influence of Hermes, whom he regards as his own personal deity, finds himself in the position in which he can see nothing but deprivation, suffering, and madness and therefore has resolved to commit suicide, but not until he can post the entire mysterious manuscript online. In the first two chapters, the reader is given what amounts to disconcerting privileged access to Korin's internal psychological malaise. We learn that he plans to leave Hungary for New York City which he believes is the "very center of the world" (33). Eventually, we learn that the title of the manuscript which is the story of four warriors journeying home after a long and bloody conflict is that of the novel in which it appears, War and War.

In the remaining six chapters, the sub-sections switch between Korin's story and portions from the mysterious manuscript - thus, we are reading War and War as we are reading War and War. As much as this narrative strategy might tell us about reading practices and the potential for art to enhance the efficacy of critical social thought, it also reveals the psychological power of the necropolitical, how necropower separates and secludes not just entire groups and populations but also individual subjects through a process of alienation and marginalization. Finally in the novel, Korin succeeds in placing the entirety of the manuscript online and does indeed follow through on his plans to commit suicide. One of the aesthetic practices of subversion of the necropolitical that Krasznahorkai employs in his novel is a kind of ludic gimmick or intertextual narrative device in which the novel directs the reader to Korin's website <http://www.warandwar.com>. Once this URL is entered into an internet browser, the following message appears: "Please be informed that your home page service has been called off due to recurring overdue payment. Attempted mail deliveries to Mr. G. Korin have been returned to sender with a note: address unknown. Consequently, all data have been erased from your home page." More than just a postmodern novelist's meditation on Barthesian or Foucauldian theories of authorship and textual production, Korin's website can be read as an example of how developing technologies of commerce and communication contain a certain subversive or liberatory potential. For while the posted message may reference explicitly so-called "death of the author" models of literary and cultural theory, the mere existence of the website calls into question anachronistic or outmoded approaches to the contemporary status of the book and material culture. Moreover, the fact that Korin's "electronic edition" of War and War has been erased by the internet service provider for non-payment of funds reveals much about the politics of historical research and how the archive functions by virtue of its relationship to a national past and collective memory. Ultimately, Korin's obsessive yet finally futile attempt to transfer, or "transition," his found manuscript out of the archive and onto a website for all humanity to see is representative of how the suppressive and ever-present forces of necropower can intercede in order to "resist the resistance." The website remains, however, as an example of how the manipulation and exploitation of new forms of textual dissemination have the capacity to participate in the attempt to subvert the global or transnational regime of repressive power formations associated with necropolitics. 
Sometimes darkly humorous and absurdly tragicomical, Kontroll and War and War are more than philosophical meditations on the psychological malaise brought upon by profound existential crisis. The texts of Antal and Krasznahorkai are political statements, allegories of national rebirth and renewal, and critiques of global structures of repression. The portrayal in Kontroll of the underground space of the Budapest subway system as a site of potential resistance against the multiple manifestations of necropower, much like Krasznahorkai's description of Korin's archive in War and War, is an aesthetic act: a moment in which the text participates in the subversion of dominant economic and political power formations. The textual articulation of a progressive or resistant politics needs to go beyond merely representing confined and oppressive subterranean spaces; both Antal and Krasznahorkai address this problematic by transitioning their respective protagonists out of the underground. Allegorical readings of both Bulcsú's and Korin's ascents out of subterranean spaces establish connective lines of inquiry to the work of some scholars who read the instant of national emergence out of authoritarian pasts as a moment of crisis, albeit one which can be productive and full of possibilities for renewal. The movements, or transitions, of both Bulcsú and Korin are reflections of the "trauma of transition" or "melancholy of rebirth" structures previously discussed and also provide intriguing models for the consideration of the efficacy of importing transitological modes of political analysis into the realm of cultural interpretation.

While questions surrounding the utility of allegorical interpretations of national literatures abound, allegory as a theoretical construct or structure of communication or meaning can be helpful for analyzing the cultural field of so-called Second World polities or, by extension, countries in a state of transition. Moreover, as a supplement to or elaboration upon transitological approaches to comparative political analysis, allegorical readings have the capacity to illuminate and explain how the processes involved in the transition out of authoritarian regimes can invest national literatures with subversive or resistant potential. As Janos observes, the transition out of an authoritarian past is not always a smooth or seamless trajectory towards Western models of liberal democracy; rather, it is a process directed and defined by the movement out of one international regime into another. Under the current dominant regime of necropolitics, with its global deployment of the forces of necropower, localized textual strategies of resistance contain within them the capacity for disruption and subversion.

What might my analytical sketches tell us about the capacity for a kind of textual articulation of a politics of resistance? At first glance it may appear that they teach us nothing as both Bulcsú and Korin find themselves in situations where the only solutions to their unbearable conditions are suicidal acts. Perhaps, however, by betraying the terrible and nefarious operations of necropower they gesture toward Mbembe's final statement that "under conditions of necropower, the lines between resistance and suicide, sacrifice and redemption, martyrdom and freedom are blurred" ("Necropolitics" 40).

\section{Works Cited}

Barany, Zoltan, and Aurel Braun, eds. Dilemmas of Transition: The Hungarian Experience. Lanham: Rowman and Littlefield, 1999.

Crawford, Beverly, and Arend Lijphart. "Explaining Political and Economic Change in Post-Communist Eastern Europe: Old Legacies, New Institutions, Hegemonic Norms, and International Pressures." Comparative Political Studies 28.2 (1995): 171-99.

Gans-Morse, Jordan. "Searching for Transitologists: Contemporary Theories of Post-Communist Transitions and the Myth of a Dominant Paradigm." Post-Soviet Affairs 20.4 (2004): 320-49.

Janos, Andrew C. "From Eastern Empire to Western Hegemony: East Central Europe Under Two International Regimes." East European Politics and Societies 15.2 (2001): 221-49.

Jobbitt, Steve. "Subterranean Dreaming: Hungarian Fantasies of Integration and Redemption." KinoKultura: New Russian Cinema 7 (2008): <http://www.kinokultura.com/specials/7/kontroll.shtml>.

Kálmán, György. "After Dictatorships: Transition, Modernity, Post-Modernity and Power." Other Modernisms in an Age of Globalization. Ed. Djelal Kadir and Dorothea Lobbermann. Heidelberg: Winter, 2002. 63-73.

Khanna, Ranjana. "Post-Palliative: Coloniality's Affective Dissonance." Postcolonial Text 2.1 (2006): (<http://postcolonial.org/index.php/pct/article/view/385/815>.

Konrad, György. The Melancholy of Rebirth: Essays from Post-Communist Central Europe, 1989-1994. Trans. Michael Henry Heim. New York: Harcourt Brace \& Co., 1995. 
Kontroll. Dir. Nimród Antal. Budapest: Café Film and Bonfire Film, 2004.

Krasznahorkai, László. War and War. Trans. George Szirtes. New York: New Directions, 2006.

Lisiak, Agata Ana. Urban Cultures in (Post)Colonial Central Europe. West Lafayette: Purdue UP, 2010.

Mbembe, Achille. "Necropolitics." Trans. Libby Meintjes. Public Culture 15.1 (2003): 11-40.

Mbembe, Achille. "Provisional Notes on the Postcolony." Africa: Journal of the International African Institute 62.1 (1992): 3-37.

Moore Chioni, David. "Is the Post- in Postcolonial the Post- in Post-Soviet?: Toward a Global Postcolonial Critique." PMLA: Publications of the Modern Language Association of America 116.1 (2001): 111-28.

O'Donnell, Guillermo, and Philippe Schmitter. Transitions from Authoritarian Rule: Tentative Conclusions About Uncertain Democracies. Baltimore: Johns Hopkins UP, 1986.

Portuges, Catherine. "Comparative Central European Culture: Austrian and Hungarian Cinema Today." Comparative Central European Culture. Ed. Steven Tötösy de Zepetnek. West Lafayette: Purdue UP, 2002. 133-47.

Spellberg, Matthew. "Treasure Trove and Record Room." The Harvard Book Review 8.1 (2006): <http://www.hcs.harvard.edu/ hbr/issues/8.1summer06/articles/warwar.shtml>.

Tötösy de Zepetnek, Steven. "Comparative Cultural Studies and the Study of Central European Culture." Comparative Central European Culture. Ed. Steven Tötösy de Zepetnek. West Lafayette: Purdue UP, 2002. 1-32.

Tötösy de Zepetnek, Steven. "Configurations of Postcoloniality and National Identity: Inbetween Peripherality and Narratives of Change." The Comparatist: Journal of the Southern Comparative Literature Association 23 (1999): 89-110.

Tötösy de Zepetnek, Steven. Comparative Literature: Theory, Method, Application. By Steven Tötösy de Zepetnek. Amsterdam: Rodopi, 1998.

Tötösy de Zepetnek, Steven. "Post-Colonialities: The 'Other,' the System, and a Personal Perspective, or, This (Too) is Comparative Literature." Postcolonial Literatures: Theory and Practice / Les Littératures postcoloniales. Théories et réalisations. Ed. Steven Tötösy de Zepetnek and Sneja Gunew. Thematic Issue Canadian Review of Comparative Literature / Revue Canadienne de Littérature Comparée 22.3-4 (1995): $399-407$.

Töttössy, Beatrice. "Hungarian Postmodernity and Post-Coloniality: The Epistemology of a Literature." Postcolonial Literatures: Theory and Practice / Les Littératures post-coloniales. Théories et réalisations. Ed. Steven Tötösy de Zepetnek and Sneja Gunew. Thematic Issue Canadian Review of Comparative Literature / Revue Canadienne de Littérature Comparée 22.3-4 (1995): 881-91.

Author's profile: Ryan Michael Kehoe is working towards his Ph.D. in English at Rice University with a dissertation entitled Chosen Countries: Utopian Fictions and Political Fantasy in Early Twentieth-century American Literature. His areas of scholarship include contemporary Central and East European literature and cinema, the early twentieth century US-American political novel, and studies in utopia. E-mail: <rmk1@rice.edu> 